ロ絵 4 : メタンハイドレート分布域の地すべりと土石流堆積物

\title{
Pictorial 4 : Slides and Debris Flow Deposits in Methane Hydrate Bearing Area
}

詳細な海底地形調査により，海鷹海脚と上越海丘上には多数のマウンドとポックマークが発達することがわかった。上越海丘の 北東の斜面には長さ $4 \mathrm{~km}$, 比高 $300 \mathrm{~m}$ の地すべりがみられ地すべりに由来する土石流堆積物が海盆に広がっている．地震波の時 間断面上に見られる BSR と地すべりの関係から，BSR 深度に沿ってメタンハイドレートの分解と堆積物の不安定化が起きたと推 定される。

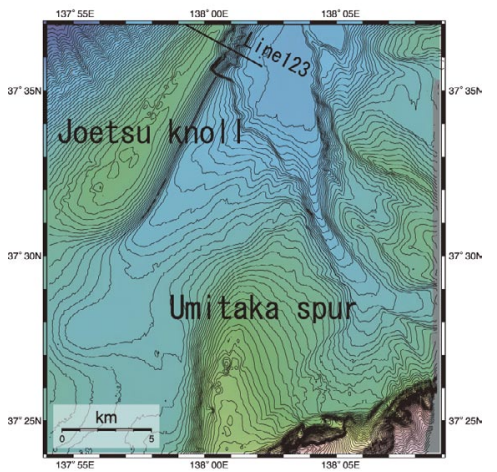

図 1 新潟県上越市沖の上越堆積盆地の位置図. 上 越海丘の北端付近の東斜面に地すべりが発達 する.この部分の地震探査断面を図 2 に示す.

Fig. 1 Location of Joetsu basin off Joetsu City, Niigata Prefecture. Slide and debris flow deposits are dominant on the eastern slope of the northern end of Joetsu knoll.
NW

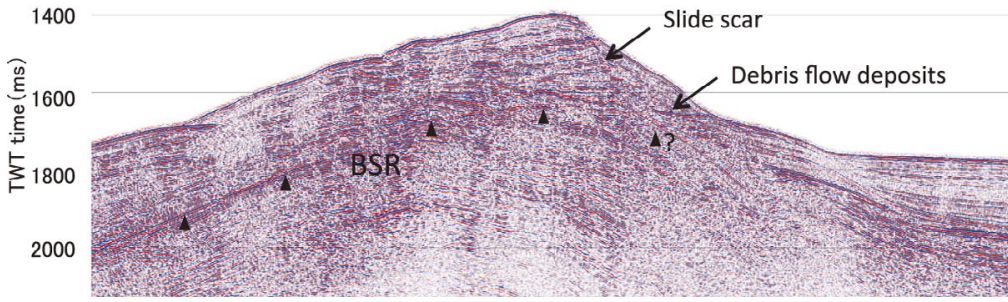

図 2

上越海丘の北部を切る地震探査の時間断面. BSR の延長上に地すべ り面が発達するようにみえる。

Fig. 2

A seismic profile of the northern end of the Joetsu knoll. BSR seems to continue to the slide scar.

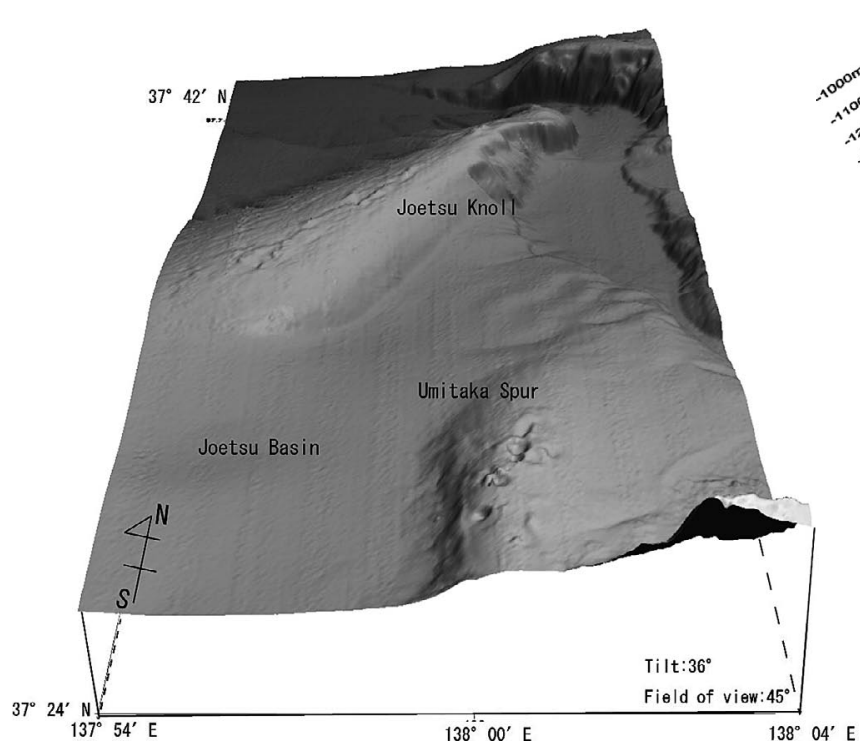

図 3 (Fig. 3)

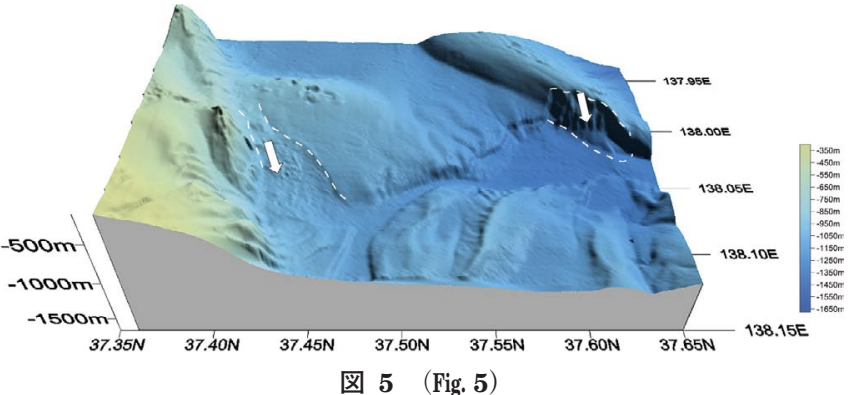

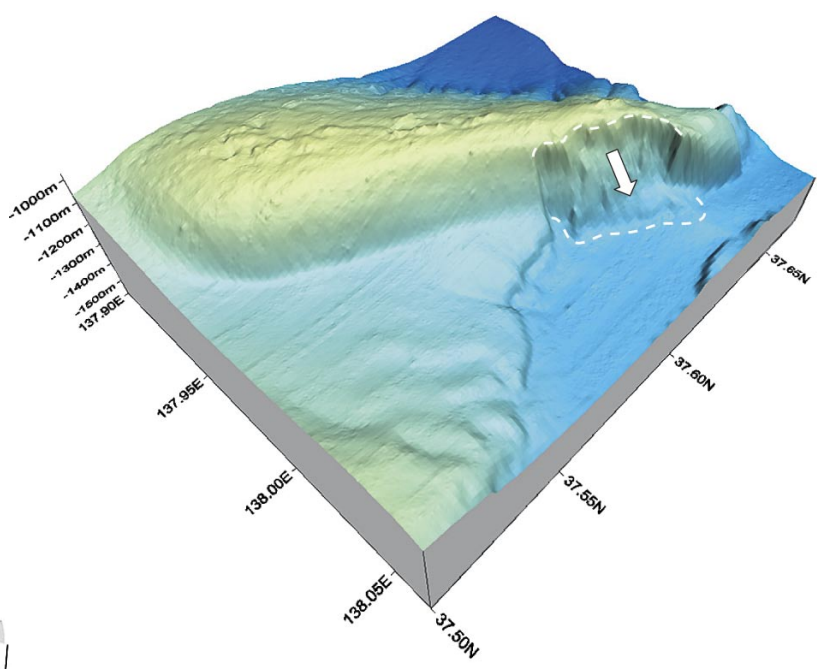

図 4 (Fig. 4)

図 3 南から北を見た 3 次元鯨観図，海鷹海脚上にポックマー クが発達するのがみえる。越海丘の北端には大規模な 地すべりが発達。

Fig. 3 South to north view of the Umitaka spur. Pockmarks have developed on Umitaka spur. A large slide at the northern end of Joetsu knoll are also remarkable.

図 4 南東から北西方向の鯨観図. 上越海丘の地すべりによ る土石流堆積物が東に張り出す。

Fig. 4 Southeast to northwest view of a 3D geographic model of the Joetsu knoll. Well developed debris flow deposits at the foot of the slide at the north-eastern part of Joetsu knoll.

図 5 東から西方向をみた鯨観図。海鷹海脚の南東にも大規 模な地すべりがみられる。

Fig. 5 East to west view of the study area. A large scale slide is also observed at the southeastern part of the Umitaka spur. 